\title{
Analysis of Student Attitudes towards E-learning: The Case of Engineering Students in Libya
}

\author{
Amal Rhema and Iwona Miliszewska \\ Victoria University, Melbourne, Victoria, Australia
}

\section{Amal.Rhema@live.vu.edu.au; Iwona.Miliszewska@vu.edu.au}

\begin{abstract}
Student attitudes and beliefs towards e-learning, as well as their satisfaction with technology and past e-learning experiences are regarded as success determinants of future e-learning initiatives. While e-learning and its potential benefits for developing countries have been discussed in the literature, research on user perspectives of e-learning in those countries is limited. This article presents findings on the experiences and perceptions of technology-supported learning gathered from engineering students at two Libyan universities. An analysis of relationships between student attitudes towards e-learning and their demographic characteristics, access to technology, use of technology for learning, skill in technology, and satisfaction with technology is also included. The reported findings might be of interest to academics, administrators, and decision-makers involved in planning, developing and implementation of future e-learning strategies in Libya and similar developing countries.
\end{abstract}

Keywords: developing country, e-learning, engineering students, information and communication technology (ICT), Libya, student attitudes, technology-supported learning.

\section{Introduction}

Many scholars agree that ICTs play an increasingly important role in facilitating the educational processes and systems of today (AL-Hunaiyyan, Al-Huwail, \& Al-Sharhan, 2008; Oh \& Park, 2009; Vaughan \& Garrison, 2006). E-learning has started to emerge in many developing countries where it has the potential to help meet an increasing demand for education and address the growing decline of trained teachers (UNESCO, 2006). The application of e-learning in developing countries has gradually advanced in recent years with an improved availability of Internet connections, local area networks, and IT support (Omidinia, Masrom, \& Selamat, 2011; Tedre, Ngubuke, \& Kempainnen, 2010; Williams, Mayer, \& Minges, 2011). However, other challenges still prevail. In those countries, the active, participative student who is required for interactive learning is rare, and the traditional methods are widely used in teaching and learning (Andersson

Material published as part of this publication, either on-line or in print, is copyrighted by the Informing Science Institute. Permission to make digital or paper copy of part or all of these works for personal or classroom use is granted without fee provided that the copies are not made or distributed for profit or commercial advantage AND that copies 1) bear this notice in full and 2) give the full citation on the first page. It is permissible to abstract these works so long as credit is given. To copy in all other cases or to republish or to post on a server or to redistribute to lists requires specific permission and payment of a fee. Contact Publisher@InformingScience.org to request redistribution permission.
\& Grönlund, 2009; Eastmond, 2000; Evans, 2005; Sehrt, 2003). In addition, the developing countries often lack the ability to implement advanced educational practices on their own (Andersson \& Grönlund, 2009).

Student characteristics are regarded as a critical success factor in e-learning in developing countries (Bhuasiri, Xaymoungkhoun, Zo, Rho, \& Ciganek, 
2012). These characteristics include computer self-efficacy, Internet self-efficacy, computer experience, Internet experience, computer anxiety, and attitudes toward e-learning (Chu \& $\mathrm{Chu}$, 2010; Chiu \& Wang, 2008; Fuller et al., 2006; Pituch \& Lee, 2006; Shih, Muñoz, \& Sanchez, 2006; Sun et al., 2008). Student attitudes are influenced by the quality and perceived ease of use of e-learning courses, functionality of e-learning platforms, and the level of student computer skills (Aixia \&Wang; 2011). Their computer experience including perceived self-efficacy, enjoyment, and usefulness of using e-learning also plays a role (Liaw \& Huang, 2011). In turn, positive student attitudes and behaviors towards e-learning are critical to their e-learning readiness and acceptance (Lim, Hong, \& Tan, 2008; Selim, 2007).

To inform the prospects of future e-learning initiatives in Libya, a study involving Libyan undergraduate engineering students was conducted in 2011-2013; the study examined the students' experiences and perceptions of e-learning to gauge their acceptance of, and preparedness for, elearning. Statistical analysis was conducted to assess student attitudes towards e-learning, and to reveal the relationships between their attitudes and their demographic characteristics, access to technology, use of technology for learning, skill in technology, and satisfaction with technology. This paper presents an overview of student attitudes towards ICT and e-learning, it outlines the factors influencing those attitudes, and it discusses the findings of the study.

\section{Related Literature}

\section{Student Attitudes towards ICT and E-learning in Developing Countries}

Research undertaken in the area of attitude and attitude formation shows that attitudes and beliefs are linked, and attitudes and behaviors are linked; moreover, attitudes are essentially divided into likes and dislikes (Siragusa \& Dixon, 2008). With the broad expansion of ICT in education during the last decade, many research studies have explored the attitudes of users (educators and students) towards the integration of ICT in education (Gasaymeh, 2009; Mishra \& Panda, 2007; Wen \& Shih, 2008).

University students in developing countries have varying attitudes towards e-learning but generally their attitudes are positive (El-Gamal \& El-Aziz, 2011). This was emphasised by Nassoura (2012) who pointed out that many students had positive attitudes towards e-learning because it had a positive impact on their motivation as well as self-esteem.

In some developing countries, the learning process and the adherence to traditional practices are inseparable. Thus, technology-based tools for e-learning are viewed as an interference with the practices that have been valued for generations. A good example of this scenario is Botswana. According to Brown, Thomas, van der Merwe and van Dyk (2008), the socio-cultural environment in Botswana is very strong. Students in Botswana's higher learning institutions are still so strongly embedded in it that their attitude towards e-learning reflects it. Despite having taken significant steps towards a Western-style economy and towards urbanisation, the country maintains strong connections to its traditional roots. According to Brown and colleagues (2008), students gain most of their knowledge from their integration with the various communities that have strong values, knowledge and beliefs.

However, the reserved attitude towards technology-based learning tools in Botswana and other developing countries is gradually disappearing, as the obvious usefulness of these tools is being realised. As Internet-enabled mobile devices are becoming more and more popular in developing countries, so is the range of areas in which they are applied; and this includes e-learning. Mobile devices such as Internet-enabled phones are very popular and are increasingly being used for blogging and social networking; this, in turn, helps improve user attitudes towards e-learning. 
According to Deb (2011) however, the physical separation between the learner and the instructor tends to create a feeling of isolation on the part of the learner leading to negative attitudes.

A 2002 survey carried out in Pakistan's Virtual University with 387 undergraduate students in their final year of study concluded that over $90 \%$ of the students viewed learning through satellite TV and the Internet as advantageous, and student attitude towards e-learning were generally positive (Hussain, 2007). Omidinia, Masrom and Selamat (2011) identified student attitudes as a factor that determined how e-learning was adopted in Iran. Selim (2007) stated users who were very familiar with web technologies and the skills needed to use computer and mobile devices for instruction developed positive attitudes. On the other hand, students who were not skilled in ICT became anxious about the use of computers, had lower expectations from educational technology, and they did not believe in the benefits of e-learning (Vrana, Garyfallos, Zafiropoulos, \& Paschaloudis, n.d.).

\section{Factors Influencing Student Attitude towards ICT and E-learning}

Student attitudes towards e-learning have been identified as critical to the success of e-learning (Zhang \& Bhattacharyya, 2008). Bhuasiri, Xaymoungkhoun, Zo, Rho and Ciganek (2012) found that in developing countries the most significant factors were related to increasing technology awareness and improving attitude toward e-learning, enhancing basic technology knowledge and skills, improving learning content, requiring computer training, motivating users to utilise elearning systems, and requiring a high level of support from the university. In addition, attributes used to assess the attitudes towards ICT of students, teachers and principals have been categorised in two groups: demographics (age and gender) and computer experience (training, years of using computer, ownership of computer, access to a computer, intensity of computer use) (Jimoyiannis \& Komis, 2007; Papaioannou \& Charalambous, 2011; Wen \& Shih, 2008).

\section{Demographic Characteristics}

Literature shows that gender plays a key role in understanding the differences in perceptions of the usefulness of technology and attitudes and perceptions of e-learning; various studies have been undertaken to investigate the effect of gender, as well as age, and year of study on student attitudes (Bertea, 2009; Cheng, 2006; Paris, 2004; Roca, Chiu, \& Martinez, 2006). Several studies revealed that male students had more positive attitudes towards e-learning than female students (Liaw \& Huang, 2011; Papaioannou \& Charalambous, 2011; Whitley, 1996).

In contrast to this, Egbo and colleagues (2011) concluded that female students tended to accept the use of ICT more than their male counterparts. Suri and Sharma (2013) found no gender differences in relation to the attitudes towards e-learning. These results are in line with some recent research studies which revealed that the gap between men and women (gender divide) is narrowing (Bhattacharjee, 2008; Gillwald, Milek, \& Stork, 2010; Imhof, Vollmeyer, \& Beierlein, 2007; Teo, 2008; UNESCO, 2012).

\section{Access to Technology}

Student levels of access to technologies represent an initial factor that would shape their attitudes towards e-learning, and their willingness to use it; the availability of reliable ICTs and the convenience of accessing these technologies reflect student attitudes toward e-learning. Access to the necessary ICT infrastructure is one of the most important issues that come into focus in the assessment of how developing countries have progressed in e-learning. The traditional means of learning, which are paper-based, are still the most commonly used in contrast to the web-based and online learning methods. According to Gulati (2008), the developing nations find the traditional means of learning more reliable and sustainable. However, Omidinia, Masrom and Selamat 
(2011) reported that the use of ICT technology for learning was widely accepted in Iran's educational institutions. The authors, however, noted that obtaining the necessary e-learning content and providing the necessary infrastructure was still a major challenge.

Tekinarslan (2008) examined computer anxiety and accessibility of personal computers between two groups of Dutch and Turkish students. The results of the study showed that the Dutch students had lower computer anxiety levels and higher levels of technology use than the Turkish students. This was explained by the relatively high levels of computer access and computer usage of the Dutch participants. Thus, in general, accessibility of technology tends to affect student and instructor attitudes and competencies and correlates positively with the level of technology use (Agyei \& Voogt, 2011). Sweeney and Geer (2010) found that limited access to ICT constrains student capabilities, attitudes and experiences; Hussain (2007) concurred. According to Hussain (2007), students selected for a study on e-learning in Pakistan indicated that they faced many difficulties in accessing ICT facilities and this limited their ability to use technologies. A large number of students had to rely on a very limited number of cafes to access the Internet for their learning needs.

\section{Technology Use and Skills}

Over the last few decades there has been increased use of computing devices in educational institutions in developing countries (Deb, 2011; Trucano, Hawkins \& Iglesias, 2012). The use of the web, computer, and mobile-based technologies has drawn a lot of interest among students, who use them for educational purposes as well as for social networking. This at least implies a degree of familiarity with these technologies and the skills for using those (Trucano et al., 2012). As mentioned above, in Pakistan, the students' ability to use ICTs was significantly hindered by the low level of technology access (Hussain 2007).

Many research studies identified correlations between positive computer experience and positive attitudes, competence and comfort with computers (Schumacher \& Morahan-Martin, 2001; Papaioannou \& Charalambous, 2011; Paris, 2004) and an inverse relationship between computer experience and computer anxiety (Busch, 1995; Olatoye, 2011). Other studies disagreed with these findings and claimed that computer experience did not play a significant role in reducing computer anxiety or developing positive computer attitudes (Felton, 2006; Pelgrum, 1993; Olatoye, 2009).

\section{Satisfaction with Technology}

Student satisfaction with e-learning environments was examined in several studies (Santhanam, Sasidharan, \& Webster, 2008; So \& Brush, 2008; Wu, Tennyson, \& Hsia, 2010; Zhu, 2012). Positive learning climate and performance expectations affect student satisfaction, and performance expectations provide the greatest contribution (total effect) to learning satisfaction. Users (students and instructors) will hold positive attitudes towards e-learning if they recognise that it would help them improve their learning and teaching effectiveness and efficiency (Rahamat et al., 2012; Wu, Tennyson, \& Hsia, 2010). Chen and Huang (2012) stated that understanding student attitudes can help expand e-learning system functions and meet student needs, which should further increase the impact of learning and enhance satisfaction with the learning process. Aixia and Wang (2011) found that the vast majority of students who were satisfied with an e-learning environment held positive believes and attitudes towards it; perceived satisfaction was identified as one of four factors that helped explain $83.8 \%$ of the variance of student attitude. 


\section{The Study}

\section{Study Questions}

The study reported in this article investigated e-learning experiences and perceptions of engineering students at two typical public Libyan universities. The results described here focus on the relationships between student attitudes towards e-learning and their demographic characteristics and experiences with ICTs. The following research questions guided the research presented in this article:

1. What are the overall attitudes of students toward technology?

2. Are there significant differences in attitudes towards technology between female and male students?

3. Are there significant differences in attitudes towards technology between urban and regional students?

4. What are the relationships between student attitudes toward technology and their access to, the use of, skill in, and satisfaction with technology?

\section{Study Design}

Data for the study was collected through a survey instrument and analysed using Statistical Package for the Social Sciences (SPSS). Descriptive statistics were used to summarise and describe the data collected from the respondents in the four participating groups. In addition, Pearson Product Moment correlations were used to examine the relationships between the variables that were measured on the interval scale. Subsequently, statistical models (multiple linear regression) were developed to relate the dependent variable to a number of student demographics and factors that may influence student attitudes towards ICT and e-learning. The dependent variable (Y) was the student attitude toward technology, while the independent variables $(X 1,2,3, \ldots$. , and 8$)$ included: (a) gender; (b) location (urban/regional); (c) ages; (d) years of study; (e) access to technologies; (f) use of technology for learning; (g) skill in technologies; and, (h) satisfaction with technologies. The additional variables, such as age and year of study were included in the model to control for possible confounding influence of these variables.

\section{Sample}

The two institutions participating in this study were the University of Tripoli, located in Libya's capital, and a regional University of Al-Jabal Al-Gharbi, which is located almost 100km southwest of Tripoli. The University of Tripoli, established in 1957, is one of the oldest and largest universities in Libya. The University of Al-Jabal Al-Gharbi, established in 1985, is one of the biggest regional universities in Libya. Both institutions are funded by the Government. The participants $(\mathrm{N}=348)$ were undergraduate engineering students from the departments of Electrical Engineering and Petroleum Engineering at each of the universities. Data was collected in 2011/2012 shortly after the cessation of the armed conflict in Libya through a paper-based questionnaire; the response rate was $45 \%$. Table 1 describes the demographic characteristics of the participants. 
Table 1. Demographic characteristics of participating students.

\begin{tabular}{|c|c|c|c|c|}
\hline & \multicolumn{2}{|c|}{$\begin{array}{l}\text { University of Tripoli } \\
\text { (Urban) }\end{array}$} & \multicolumn{2}{|c|}{$\begin{array}{l}\text { University of Al-Jabal Al-Gharbi } \\
\text { (Regional) }\end{array}$} \\
\hline Demographic & $\begin{array}{c}\text { Group A } \\
\text { Elec. Eng. } \\
\begin{array}{c}N=125 \\
n(\%)\end{array}\end{array}$ & $\begin{array}{c}\text { Group B } \\
\text { Petr. Eng. } \\
\begin{array}{c}N=105 \\
n(\%)\end{array}\end{array}$ & $\begin{array}{c}\text { Group C } \\
\text { Elec. Eng. } \\
\begin{array}{c}N=45 \\
n(\%)\end{array}\end{array}$ & $\begin{array}{c}\text { Group D } \\
\text { Petr. Eng. } \\
\begin{array}{c}N=73 \\
n(\%)\end{array}\end{array}$ \\
\hline $\begin{array}{r}\text { Female } \\
\text { Male }\end{array}$ & $\begin{array}{ll}77 & (62) \\
48 & (38)\end{array}$ & $\begin{array}{ll}49 & (47) \\
56 & (53)\end{array}$ & $\begin{array}{ll}21 & (47) \\
24 & (53)\end{array}$ & $\begin{array}{ll}56 & (77) \\
17 & (23)\end{array}$ \\
\hline $\begin{array}{l}\text { Age } \\
\qquad \begin{array}{r}18-20 \\
21-22 \\
\geq \quad 23\end{array}\end{array}$ & $\begin{array}{ll}20 & (16) \\
46 & (37) \\
59 & (47)\end{array}$ & $\begin{array}{ll}11 & (11) \\
32 & (30) \\
62 & (59)\end{array}$ & $\begin{aligned} 9 & (20) \\
20 & (44) \\
16 & (36)\end{aligned}$ & $\begin{array}{ll}28 & (38) \\
24 & (33) \\
21 & (29)\end{array}$ \\
\hline $\begin{array}{r}2 \\
3 \\
\geq \quad 4\end{array}$ & $\begin{aligned} 9 & (7) \\
13 & (10) \\
41 & (33) \\
62 & (50)\end{aligned}$ & $\begin{aligned} 13 & (12) \\
7 & (7) \\
40 & (38) \\
45 & (43)\end{aligned}$ & $\begin{aligned} 4 & (9) \\
17 & (38) \\
12 & (27) \\
12 & (26)\end{aligned}$ & $\begin{array}{ll}17 & (23) \\
24 & (33) \\
12 & (16) \\
20 & (28)\end{array}$ \\
\hline
\end{tabular}

\section{Survey Methodology}

Closed, quantitative questions (statements) were developed based on a number of studies conducted to measure student attitudes towards technology (Mishra \& Panda, 2007; Gasaymeh, 2009). Participants were asked to rate eight statements using a rating scale from " 1 " "strongly disagree' to " 5 " 'strongly agree' to indicate their attitude towards technology in learning.

An instrument developed by Kennedy et al. $(2006 ; 2008)$ was adopted and modified to accommodate the needs of this study. The survey section "Access to Technology" consisted of ten items (technologies) and students were asked to indicate their level of access outside the university. The options provided were: "No access", "Limited or inconvenient access", and "No problem with access".

Students were also asked to indicate how they used various technologies and their levels of skill with these technologies. They could choose between: "Don't know this technology", "To support learning", and "For other purposes". Students were allowed to select both "To support learning" and "For other purposes" if the two options applied to them. They were also asked to apply a rating scale (from " 1 " 'not skilled at all'; to "5" 'very skilled') to indicate their levels of skill in using these technologies.

To measure participant satisfaction with technology, a published survey called Teleconference Evaluation Questionnaire (Biner, 1993) was adapted and used. The survey section "Technological Characteristics and Technical Support" consisted of nine statements. Students were asked to indicate their level of satisfaction with the provided statements. They were asked to apply a rating 
scale (from " 1 " "very poor' to " 5 " "very good') to indicate the level to which they rated their satisfaction with technology (Appendix A).

The reliability of the quantitative data in this study was determined by finding Cronbach's Alpha of the pilot survey data using IBM SPSS v. 21. The reliability results for the pilot survey are presented in Table 2.

Table 2. Reliability of pilot survey - assessment of Cronbach's Alpha.

\begin{tabular}{|l|c|c|}
\hline \multicolumn{1}{|c|}{ Scale } & Number of survey items & Cronbach's Alpha \\
\hline Access to technology & 10 & 0.75 \\
\hline Use of and skill in technology & 25 & 0.93 \\
\hline Usefulness of technology & 22 & 0.89 \\
\hline Satisfaction with technology & 9 & 0.86 \\
\hline Attitude towards technology & 8 & 0.86 \\
\hline
\end{tabular}

\section{Study Results}

\section{Student Attitudes towards Technology}

To determine which items accounted for positive student attitudes, an item analysis of responses to the survey was conducted by collapsing the two measures of 'strongly agree' and 'agree', and 'strongly disagree' and 'disagree'. Considering 'agree' with statements as indicators of positive attitudes, it was apparent that the range of percentages under the 'agree' category was $63-93 \%$, as compared to $0-12 \%$ under the 'disagree' category. The analyses of the overall scores on the attitude scale indicated that students' overall responses to this scale were positive. Table 3 presents the means for each item on the attitude scale for female and male students in all student groups.

Table 3 shows that all the participating students had positive attitudes towards ICT and elearning; they felt confident in using computers, enjoyed using ICTs in their studies, believed in the benefits of e-learning, and would be interested in studying courses that used e-learning. In particular, students believed strongly that e-learning would give them the opportunity to acquire new knowledge and enhance their learning experiences; the mean values scored more than 4 . On the other hand, students reported moderate enjoyment of using ICT for studies; the mean values scored less than 4. 
Table 3: Means for student attitudes towards technology by group and gender

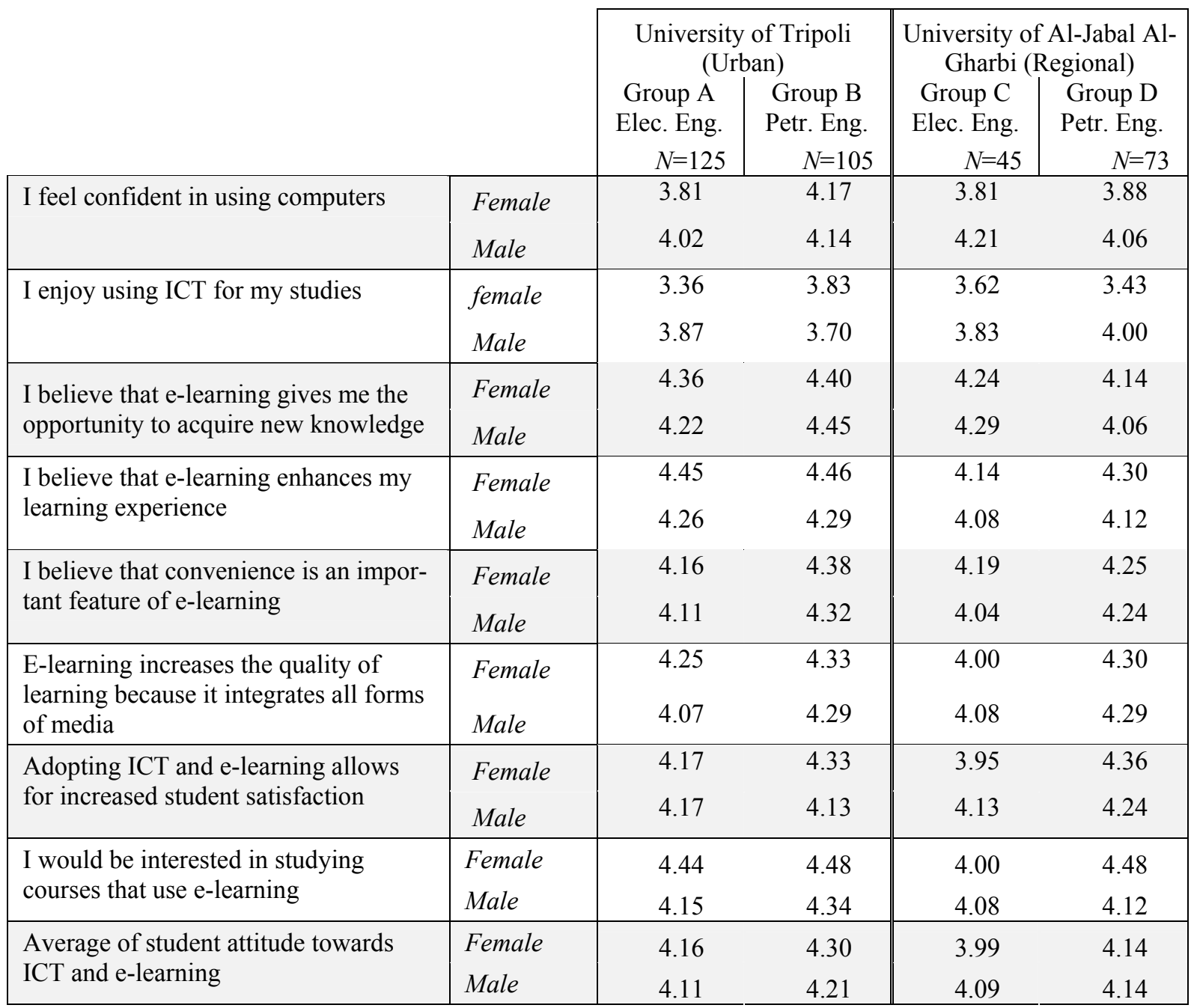

\section{Differences between Female and Male Students, and between Urban and Regional Students}

Overall, the results showed that female and male students had positive attitudes towards technology (see Table 3 and Figure 1). However, in urban groups A and B, female students were more likely to hold positive attitudes than male students. Table 3 and Figure 1 also show that students in all groups had positive attitudes towards technology. However, students in the urban Group B reported slightly higher positive attitudes towards technology; rural Group C students reported lower levels of all. 


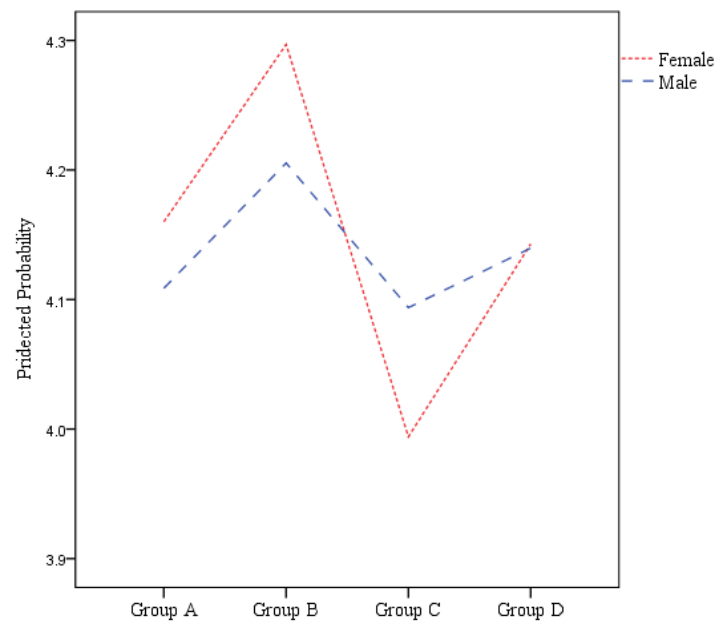

Figure 1: students' level of attitudes towards e-learning by group and gender

In groups $\mathrm{A}, \mathrm{C}$ and $\mathrm{D}$, male students felt more confident in using computers and enjoyed using ICT for their studies more than the female students, whereas female students believed stronger that e-learning enhanced their learning experience. Female students in groups A, B and D felt more interested in studying courses that use e-learning compared to their male counterparts.

While the descriptive analysis shows that there were slight differences between female and male students and between urban and rural students in their attitudes towards the statements provided in Table 3, the results of the multiple regression model provided in Table 4 show that there was no significant difference between the genders. They also illustrate that there was no significant difference in the level of attitudes towards ICT and e-learning between the urban and regional groups.

Furthermore, the results provided in Table 4 show that there were no significant differences in the levels of attitudes towards ICT and e-learning between younger and older students, or first year students and students in other years of study.

\section{The Relationships between Student Attitudes towards Technology and Other Factors}

Student attitudes were checked against their overall levels of access to technology, skill, and satisfaction to explore possible relationships.

As illustrated in Figure 2, the relationships were approximately linear between student attitudes/beliefs and other variables: student access to technologies, student use of technology for learning, student skill in technologies, and student satisfaction with technologies. The Pearson Product Moment correlation coefficients were used to measure the relationships between the variables. The correlation coefficients were interpreted by using Davis (1971) descriptors (negligible $=0.00$ to 0.09 ; low $=0.10$ to 0.29 ; moderate $=0.30$ to 0.49 ; substantial $=0.50$ to 0.69 ; very strong $=0.70$ to 1.00$)$. There was a moderate positive relationship $(\mathrm{r}=0.45, \mathrm{p}<0.01)$ between student attitudes/beliefs towards ICT and e-learning and their levels of skills in technology-based tools. The results also show a moderate positive correlation between student attitudes/beliefs and their levels of access to various technologies $(r=0.30, p<0.01)$. Moreover, a substantial positive relationship $(r=0.56, p<0.01)$ was found between student level of skill in technology-based tools and their level of access to a range of technologies. 


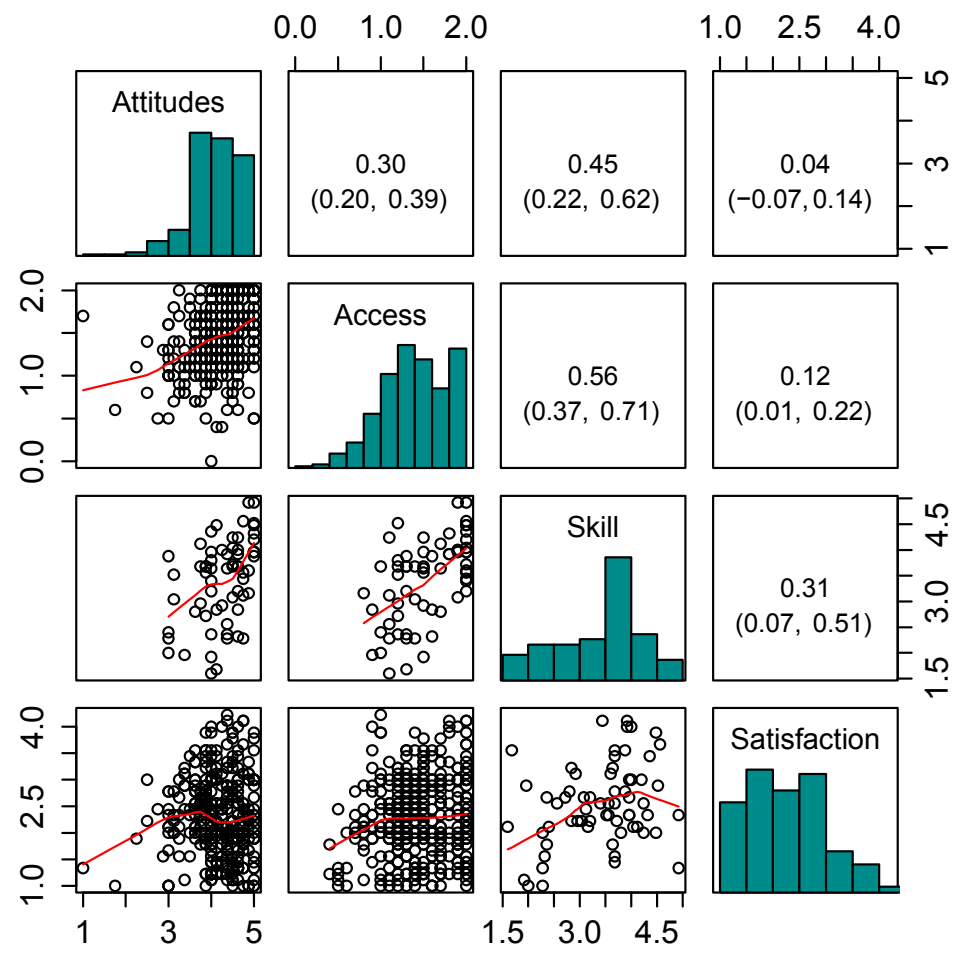

Figure 2. Scatterplots (lower triangle), histograms (diagonal), and correlations with $\mathbf{9 5 \%}$ confidence intervals (upper triangle) for student average scores on attitudes/beliefs, access, skill and satisfaction levels.

To study the relationships between student attitudes/beliefs (the dependent variable) and their characteristics including gender, study group, age, year level, level of access to technology, use of technology for learning, level of skill in technology, and satisfaction with technology, a multiple regression analysis was conducted (Table 4). The dependent variable was moderately skewed to the left (skewness statistic $=-1.086, \mathrm{SE}=0.132$; kurtosis statistic $=2.787, \mathrm{SE}=0.263$ ).

Table 4 shows that only the level of skill was statistically significant $(t=2.822 ; p=0.007)$. There was no significant difference between female and male students, or between urban and regional students with respect to their attitudes towards ICT and e-learning. While the model was significant at the 0.05 level of significance $(F(4,54)=5.73 ; p=0.001)$, only $25 \%$ of the variance in student attitudes was explained by the independent variables included in this model (Adjusted $R$ Square $=0.246$ ) - further details are presented in Appendix B. 
Table 4. Multiple regression model for student attitudes/beliefs towards ICT and e-learning.

\begin{tabular}{|c|ll|}
\hline Variable & B & SE \\
\hline Constant & 2.27 & 0.52 \\
Gender (Male) & -0.10 & 0.16 \\
Group B & 0.18 & 0.19 \\
Group C & 0.08 & 0.33 \\
Group D & 0.01 & 0.30 \\
Age 21-22 & -0.08 & 0.33 \\
Age 23 & -0.52 & 0.36 \\
Year 2 & 0.26 & 0.31 \\
Year 3 & 0.41 & 0.37 \\
Year 2 4 & 0.58 & 0.37 \\
Access & 0.09 & 0.25 \\
Use & 0.49 & 0.40 \\
Skill & 0.32 & 0.11 \\
Satisfaction & 0.13 & 0.11 \\
\hline
\end{tabular}

$* p<0.05, * * p<0.01, * * * p<0.001$

\section{Discussion and Conclusions}

This article presented findings from a larger study examining Libyan engineering students' experiences and perceptions of technology-supported learning. A comparative analysis indicated that the participating students in the urban and regional areas were positively disposed towards elearning and believed in its benefits. The positive attitudes and the willingness of students to engage in e-learning courses suggest that future e-learning initiatives have great potential in Libya. These findings are comparable with the results of a study conducted in Punjab University in India by Suri and Sharma (2013), a study conducted in the Gulf region by Al-Doub, Goodwin and AlHunaiyyan (2011), as well as with the outcomes of a study conducted in Saudi Arabian Universities by Hussein (2011).

Regarding gender impact, this study found that both female and male students held relatively similar positive attitudes towards ICT and e-learning. This aligns with the findings reported by Hussein (2011) who found no statistically significant differences between the attitudes of male and female students in Saudi universities. Moreover, the effects of other demographic characteristics such as student location (urban/rural), age, and year of study were not statistically significant in terms of their attitudes towards e-learning.

The study demonstrated that there was a statistically significant correlation between student attitudes toward technology and their levels of access to various technologies; unsurprisingly, students who had better access to technology and the Internet generated stronger positive attitudes. According to the literature, the level of access to technology and its reliability influence student 
intentions to use ICTs to support learning (Papaioannou \& Charalambous, 2011; Paris, 2004; Sweeney \& Geer, 2010). This study showed that a student skill in technologies is a significant predictor of attitudes toward ICT and e-learning, which supports previous research findings reported in the literature (Liaw, Chang, Hung, \& Huang, 2006; Liaw \& Huang, 2003; Liaw \& Huang, 2011; Mitra, 1998).

For Libya, one of greatest challenges post the 2011 armed conflict is the reconstruction and redevelopment of the country's education system (Rhema, \& Miliszewska, 2012). It has been suggested in the literature that ICT and e-learning could be used to support the affected learners and instructors in Libya, to increase access to, and to improve the relevance and quality of, higher education (Achimugu, Oluwagbemi, \& Oluwaranti, 2010; Aktaruzzaman, Shamim, \& Clement, 2011). The positive attitudes and the willingness of students to engage in e-learning courses suggest that there is a great potential for e-learning initiatives in Libya. The findings of this study could serve as a predictor of the attitudes of future students towards e-learning. They can be considered as a source of information for academics, administrators, researchers and decision-makers involved in planning, design, implementation and promotion of e-learning in Libya.

However, for e-learning to be widely accepted in higher education institutions in Libya, there is a need for the provision of appropriate training at different levels, the development of expertise in e-learning use, and research to gather data and inform future developments. These are important tasks that require substantial attention and great effort from the Libyan government to ensure the development of adequate awareness, positive attitudes, and improved motivation towards elearning.

A potential limitation comes from the use of a paper-based survey questionnaire. As reported in the literature, such questionnaires may suffer from low response rates and misinterpretation issues. It is significant to note that while the findings presented in this article provide beneficial insights which extend the limited body of work related to e-learning in Libya, they are based on a study of only two institutions and a limited number of participants. In addition, engineering students may be more technically-minded and accepting of e-learning than students of other disciplines; this might also limit the generalisation of the study findings. It would be useful to see if the findings presented in this article could be expanded to participants from other disciplines and other universities in Libya.

\section{References}

Achimugu, P., Oluwagbemi, O., \& Oluwaranti, A. (2010). An evaluation of the impact of ICT diffusion in Nigeria's higher educational institutions. Journal of Information Technology Impact, 10(1), 25-34. Retrieved July 6, 2011 from http://www.jiti.net/v10/jiti.v10n1.025-034.pdf

Agyei, D. D., \& Voogt, J. M. (2011). Exploring the potential of the will, skill, tool model in Ghana: Predicting prospective and practicing teachers' use of technology. Computers \& Education, 56(2011), 91100 .

Aixia, D., \& Wang, D. (2011). Factors influencing learner attitudes toward e-learning and development of e-learning environment based on the integrated e-learning platform. International Journal of eEducation, e-Business, e-Management and e-Learning, 1(3), 264-268. Retrieved May 4, 2013 from http://www.ijeeee.org/Papers/043-Z0031.pdf

Aktaruzzaman, M., Shamim, M., \& Clement, C. (2011). Trends and issues to integrate ICT in teaching learning for the future world of education. International Journal of Engineering \& Technology, 11(3), 114-119. Retrieved July 6, 2011 from http://www.ijens.org/Vol\%2011\%20I\%2003/1186030202\%20IJET-IJENS.pdf

AL-Hunaiyyan, A., Al-Huwail. N., \& Al-Sharhan, S. (2008). Blended e-learning design: Discussion of cultural issues. International Journal of Cyber Society and Education, 1(1), 17-32. 
Andersson, A., \& Grönlund, A. (2009). A conceptual framework for E-learning in developing countries: A critical review of research challenges. The Electronic Journal on Information Systems in Developing Countries, 38(2), 1-16.

Bertea, P. (2009). Measuring students' attitude towards e-learning: A case study. Proceedings of $5^{\text {th }}$ International Scientific Conference on e-Learning and Software for Education, Bucharest, April 9th-10th.

Biner, P. M. (1993). The development of an instrument to measurer student attitudes toward televised course. The American Journal of Distance Education, 7(1), 62-70.

Bhattacharjee, B. (2008). Factors affecting computer use among older adult users: A study in the backdrop of the Florida State University. PhD Thesis, College of Information, The Florida State University. Retrieved May 5, 2013 from http://diginole.lib.fsu.edu/cgi/viewcontent.cgi?article=2284\&context=etd

Bhuasiri, W., Xaymoungkhoun, O., Zo, H., Rho, J, J., \& Ciganek, A, P. (2012). Critical success factors for e-learning in developing countries: A comparative analysis between ICT experts and faculty. Computers \& Education, 58 (2012), 843-855.

Busch, T. (1995). Gender differences in self-efficacy and attitudes toward computers. Journal of Educational Computing Research, 12(2), 147-158.

Chen, H. R., \& Huang, J. G. (2012). Exploring learner attitudes toward web-based recommendation learning service system for interdisciplinary applications. Educational Technology \& Society, 15(2), 89100. Retrieved May 5, 2013 from http://www.ifets.info/journals/15_2/9.pdf

Cheng, K. (2006). A research study on students' level of acceptance in applying e-learning for business course: A case study on a Technical College in Taiwan. Journal of American Academy of Business, $8(2), 265-272$.

Chiu, C. M., \& Wang, E. T. G. (2008). Understanding web-based learning continuance intention: The role of subjective task value. Information \& Management, 45(3), 194-201.

Chu, R. J., \& Chu, A. Z. (2010). Multi-level analysis of peer support, internet self-efficacy and e-learning outcomes - the contextual effects of collectivism and group potency. Computers \& Education, 55(1), $145-154$.

Deb, S. (2011). Effective long distance learning in developing countries using mobile and multimedia technology. International Journal of Multimedia and Ubiquitous Engineering, 6(2), 33-40.

Eastmond, D. (2000). Realizing the promise of distance education in low technology countries. Educational Technology Research and Development, 48(2), 100-111.

Egbo, O. P., Okoyeuzu, C. R., Ifeanacho, I. C., \& Onwumere, J. U. (2011). Gender perception and attitude towards e-learning: A case of business students, University of Nigeria. International Journal of Computer Application, 1(2), 135-148.

Evans, R. (2005). Explaining low learner participation during interactive television instruction in a developing country context. PhD Thesis, University of Pretoria, Pretoria. Retrieved November 19, 2010 from http://upetd.up.ac.za/thesis/submitted/etd-02282005-081708/unrestricted/00front.pdf

Felton, F. S. (2006). The use of computers by primary school principals. PhD Thesis, Virginia Polytechnic Institute and State University, Blacksburg, Virginia. Retrieved May 5, 2013 from http://scholar.lib.vt.edu/theses/available/etd-04242006-144854/unrestricted/FFelton04202006.pdf

Fuller, R. M., Vician, C., \& Brown, S. A. (2006). E-learning and individual characteristics: the role of the computer anxiety and communication apprehension. Journal of Computer Information Systems, 46(4), $103-115$.

Gasaymeh, A. (2009). A study of faculty attitudes toward internet-based distance education: A survey of two Jordanian public universities. $\mathrm{PhD}$ Thesis, the College of Education, Ohio University, Ohio, USA.

Gillwald, A., Milek, A., \& Stork, C. (2010). Towards evidence-based ICT policy and regulation: Gender assessment of ICT access and usage in Africa. Research ICT in Africa, 1(2010). Retrieved October 17, 2012 from http://lirneasia.net/wp-content/uploads/2010/09//Gender_Paper_Sept_2010.pdf 
Gulati, S. (2008). Technology-enhanced learning in developing nations: A review. International Review of Research in Open and Distance Learning, 9(1), 1-16.

Hussain, I. (2007). A study of student's attitude towards virtual education in Pakistan. Turkish Journal of Distance Learning, 8(2), 69-79. Retrieved February 26, 2013 from http://tojde.anadolu.edu.tr/tojde26/pdf/article 6.pdf

Imhof, M., Vollmeyer, R., \& Beierlein C. (2007). Computer use and the gender gap: The issue of access, use, motivation, and performance. Computers in Human Behavior, 23(2007), 2823-2837.

Jimoyiannis, A., \& Komis, V. (2007). Examining teachers' beliefs about ICT in education: Implications of a teacher preparation programme. Teacher Development, 11(2), 149-173.

Kennedy, G., Krause, K., Churchward, A., Judd, T., \& Gray, K. (2006). First year students' experiences with technology: Are they really digital natives?. Centre for Studies in Higher Education and the Biomedical Multimedia Unit, Melbourne University, Melbourne, Australia. Retrieved December 5, 2010 from http://www.bmu.unimelb.edu.au/research/munatives/natives report2006.pdf

Kennedy, G., Churchward, A., Judd, T., Gray, K., \& Krause, K. (2008). First year students' experiences with technology: Are they really digital natives? Australasian Journal of Educational Technology, 24(1), 108-122. Retrieved December 5, 2010 from http://www.ascilite.org.au/ajet/ajet24/kennedy.pdf

Liaw, S. S., \& Huang, H. M. (2011). A study of investigating learners' attitudes toward e-learning. $20115^{\text {th }}$ International Conference on Distance Learning and Education, 12(2011), IACSIT Press, Singapore, 28-32. Retrieved May 4, 2013 from http://www.ipcsit.com/vol12/6-ICDLE2011E0014.pdf

Liaw, S. S., \& Huang, H. M. (2003). An investigation of user attitudes toward search engines as an information retrieval tool. Computers in Human Behavior, 19(6), 751-765.

Lim, B., Hong, K. S., \& Tan, K.W. (2008). Acceptance of e-learning among distance learners: A Malaysian perspective. In Hello! Where are you in the landscape of educational technology? Proceedings ascilite Melbourne 2008. Retrieved May 4, 2013 from http://www.ascilite.org.au/conferences/melbourne08/procs/lim.pdf

Mishra, S., \& Panda, S. (2007). Development and factor analysis of an instrument to measure faculty attitude towards e-learning. Asian Journal of Distance Education, 5(1), 27-33.

Mitra, A. (1998). Categories of computer use and their relationships with attitudes toward computers. Journal of Research on Computing in Education, 30(3), 281-295.

Nassoura, A. B. (2012). Students' acceptance of mobile learning for higher education in Saudi Arabia. American Academic \& Scholarly Research Journal, 4(2). Retrieved January 20, 2013 from http://aasrc.org/aasrj/index.php/aasrj/article/download/248/188

Oh, E., \& Park, S. (2009). How are universities involved in blended instruction? Educational Technology \& Society, 12(3), 327-342.

Olatoye, R. A. (2009). Influence of computer anxiety and knowledge on computer utilization of senior secondary school students. Electronic Journal of Research in Education Psychology, 7(3), 1269-1288. Retrieved August 1, 2013 from http://www.investigacionpsicopedagogica.com/revista/articulos/19/english/Art_19 360.pdf

Olatoye, R. (2011). Levels of participation in ICT training programmes, computer anxiety and ICT utilization among selected professionals. International Journal of Education and Development using Information and Communication Technology, 7(2), 15-26.

Omidinia, S., Masrom, M., \& Selamat, H. (2011). Review of e-learning and ICT infrastructure in developing countries (Case study of Iran). American Journal of Economics and Business Administration, 3(1), 120-125. Retrieved January 22, 2013 from http://thescipub.com/pdf/10.3844/ajebasp.2011.120.125

Papaioannou, P., \& Charalambous, K. (2011). Principals' attitudes towards ICT and their perceptions about the factors that facilitate or inhibit ICT integration in primary schools of Cyprus. Journal of Information Technology Education, 10, 349-369. Retrieved May 4, 2013 from http://www.jite.org/documents/Vol10/JITEv10p349-369Papaioannou958.pdf 
Paris, P, G. (2004). E-learning: A study on secondary students' attitudes towards online web assisted learning. International Education Journal, 5(1), 98-112. Retrieved May 1, 2013 from http://ehlt.flinders.edu.au/education/iej/articles/v5n1/paris/paper.pdf

Pelgrum, W. J. (1993). Attitudes of school principals and teachers towards computers: Does it matter what they think? Studies in Educational Evaluation, 19(2), 199-212.

Pituch, K. A., \& Lee, Y. K. (2006). The influence of system characteristics on e-learning use. Computers \& Education, 47(2), 222-244.

Rahamat, R., Shah, P. M., Din, R., Puteh, S. N., Aziz, J. A., Norman, H., \& Embi, M. A. (2012). Measuring learners' perceived satisfaction towards e-learning material and environment. WSEAS Transactions on Advances in Engineering Education, 3(9), 72-83. Retrieved May 5, 2013 from http://www.wseas.org/multimedia/journals/education/2012/55-355.pdf

Brown,C., Thomas, H., van der Merwe, A., \& van Dyk, L. (2008). The impact of South Africa's ICT infrastructure on higher education. In D. Remenyi (Ed.), $3^{\text {rd }}$ International Conference on E-Learning: ICEL 2008, Cape Town, South Africa. Academic Publishing Limited. Retrieved October 5, 2012 from http://www.cet.uct.ac.za/files/file/ResearchOutput/2008 ICEL_Landscape.pdf

Rhema, A., \& Miliszewska, I. (2012). The potential of e-learning in assisting post-crisis countries in rebuilding their higher education systems: The case of Libya. Issues in Informing Science and Information Technology, 9, 149-160. Retrieved from http://iisit.org/Vol9/IISITv9p149-160Rhema033.pdf

Roca, J. C., Chiu, C-M. \& Martinez, F. J. (2006). Understanding e-learning continuance intention: An extension of the TAM. International Journal of Human- Computer Studies, 64(2006), 683-696

Santhanam, R., Sasidharan, S., \& Webster, J. (2008). Using self-regulatory learning to enhance e-learningbased information technology training. Information Systems Research, 19(1), 26-47.

Schumacher, P., \& Morahan-Martin, J. (2001). Gender, internet and computer attitudes and experiences. Computers in Human Behavior, 17(1), 95-110.

Sehrt, M. (2003). E-learning in the developing countries - Digital divide into digital opportunities. UN Chronicle Online, 4(3), 45-46.

Selim, H. M. (2007). Critical success factors for e-learning acceptance: Confirmatory factor models. Computers and Education, 49(2007) 396-413. Retrieved May 3, 2013, from http://www.qou.edu/arabic/researchProgram/eLearningResearchs/criticalSuccess.pdf

Shih, P., Muñoz, D., \& Sanchez, F. (2006). The effect of previous experience with information and communication technologies on performance in a web-based learning program. Computers in Human Behavior, 22(6), 962-970.

Siragusa, L., \& Dixon, K. (2008). Planned behaviour: Student attitudes towards the use of ICT interactions in higher education. In Hello! Where are you in the landscape of educational technology? Proceedings ascilite Melbourne 2008. Retrieved May 3, 2013, from http://www.swaraunib.com/indra/Sistem\%20informasi/TPB/siragusa.pdf

So, H-J., \& Brush, T. A. (2008) Student perceptions of collaborative learning, social presence and satisfaction in a blended learning environment: Relationships and critical factors. Computers \& Education, 51(1), 318-336.

Sun, P. C., Tsai, R. J., Finger, G., Chen, Y. Y., \& Yeh, D. (2008). What drives a successful e-learning? An empirical investigation of the critical factors influencing learner satisfaction. Computers \& Education, 50(4), 1183-1202.

Suri, G., \& Sharma, S. (2013). The impact of gender on attitude towards computer technology and elearning: An exploratory study of Punjab University, India. International Journal of Engineering Research, 2(2), 132-136. Retrieved May 31, 2013 from http://www.ijer.in/ijer/publication/v2s2/paper22.pdf 
Sweeney, T., \& Geer. R. (2010). Student capabilities and attitudes towards ICT in the early years. Australian Educational Computing, 25(2010), 18-24. Retrieved May 5, 2013 from http://acce.edu.au/sites/acce.edu.au/files/pj/journal/AEC Vol 25 No 1StudentCapabilities.pdf

Tedre, M., Ngubuke, F., \& Kempainnen, J. (2010). Infrastructure, human capacity and high hope: A decade of development of e-learning in a Tanzanian HEI. Revista de Universidady Sociedad del Conocimniento, 8(1), 7-20.

Tekinarslan, E. (2008). Computer anxiety: A cross-cultural comparative study of Dutch and Turkish university students. Computers in Human Behavior, 24(2008), 1572-1584.

Teo, T. (2008). Pre-service teachers' attitudes towards computer use: A Singapore survey. Australasian Journal of Educational Technology, 24(4), 413-424.

Trucano, M., Hawkins, R., \& Iglesias, C. J. (2012). Ten trends in technology use in education in developing countries that you may not have heard about. A World Bank Blog on ICT use in Education. Retrieved January 24, 2013 from http://blogs.worldbank.org/edutech/some-more-trends

UNESCO. (2006). Teachers and educational quality: Monitoring global needs for 2015. Retrieved September 20, 2009 from http://www.uis.unesco.org/TEMPLATE/pdf/Teachers2006/TeachersReport.pdf

UNESCO. (2012). Turning on mobile learning in Africa and the Middle East. Retrieved October 15, 2012 from http://unesdoc.unesco.org/images/0021/002163/216359e.pdf

Vaughan, N., \& Garrison, R. (2006). A blended faculty community of inquiry: Linking leadership, course redesign and evaluation. Canadian Journal of University Continuing Education, 32(2), 67-92. Retrieved December 30, 2010 from http://www.extension.usask.ca/CJUCE/articles/v32pdf/3223.pdf

Vrana, V., Fragidis, G., Zafiropoulos, C., \& Paschaloudis, D. (nd). Analysing academic staff and students' attitudes towards the adoption of e-learning. Retrieved May 5, 2013 from http://asiapacificodl.oum.edu.my/C70/F275.pdf

Wen, J. R., \& Shih, W. L. (2008). Exploring the information literacy competence standards for elementary and high school teachers. Computers \& Education, 50(3), 787-806.

Whitley, B. E. (1996). Gender differences in computer-related attitudes: It depends on what you ask. Computers in Human Behavior, 12(2), 275-289.

Williams, M. J., Mayer, R., \& Minges, M. (2011). Africa's ICT infrastructure building on the mobile revolution. The World Bank. Retrieved May 5, 2013 from http://siteresources.worldbank.org/INFORMATIONANDCOMMUNICATIONANDTECHNOLOGIE S/Resources/AfricasICTInfrastructure_Building_on_MobileRevolution_2011.pdf

Wu, J-H., Tennyson, R. D., \& Hsia, T-L. (2010). A study of student satisfaction in a blended e-learning system environment. Computers \& Education, 55(1), 155-164.

Zhang, P., \& Bhattacharyya, S. (2008). Students' views of a learning management system: A longitudinal qualitative study. The Communications of the Association for Information Systems, 23(2008), 351-374.

Zhu, C. (2012). Student satisfaction, performance and knowledge construction in online collaborative learning. Educational Technology and Society, 15(1), 127-136. Retrieved May 5, 2013 from http://www.ifets.info/journals/15_1/12.pdf 


\section{Appendix A}

\section{Experiences with and perceptions of ICT and E-learning Survey for Students}

Section 1: Demographics

Gender: $\square$ Male $\square$ Female
Age:
ㄱ $18-20$
ㄱ $21-22$
$\square 23$ and older

Year of studies: $\begin{array}{llll}\square & \square 2 & \square 3 & \square 4 \text { and higher }\end{array}$

Section 2: Access to Technology

Please indicate your level of access to different types of technologies (outside University). Please tick only one answer.

\begin{tabular}{|l|c|c|c|}
\hline \multicolumn{1}{|c|}{ Types of Technology } & No Access & $\begin{array}{c}\text { Limited or } \\
\text { Inconvenient Access }\end{array}$ & $\begin{array}{c}\text { No Problem } \\
\text { with Access }\end{array}$ \\
\hline Desktop computer & $\square$ & $\square$ & $\square$ \\
\hline Portable computer (i.e. laptop or notebook) & $\square$ & $\square$ & $\square$ \\
\hline Dedicated digital camera & $\square$ & $\square$ & $\square$ \\
\hline Mobile phone & $\square$ & $\square$ & $\square$ \\
\hline Video (3G) capable phones & $\square$ & $\square$ & $\square$ \\
\hline Memory stick (e.g. flash drive, USB stick) & $\square$ & $\square$ & $\square$ \\
\hline Web cam & $\square$ & $\square$ & $\square$ \\
\hline Dial-up internet access & $\square$ & $\square$ & $\square$ \\
\hline Broadband internet access (ADSL or cable) & $\square$ & $\square$ & $\square$ \\
\hline Wireless internet access & $\square$ & $\square$ & $\square$ \\
\hline
\end{tabular}

\section{Section 3: Use of Technology}

Below is a list of different ways in which ICT can be used. Please indicate:

1. If you have used technology for learning purposes and/or other purposes (e.g. entertainment); tick all that apply.

2. How skilled you are at using technology in general; circle the number that best represents your opinion -1 indicates "Not Skilled at All" and 5 indicates "Very Skilled".

\begin{tabular}{|l|c|c|c|c|c|c|c|c}
\hline \multicolumn{1}{|c|}{ Types of Technology } & $\begin{array}{c}\text { For } \\
\text { learning }\end{array}$ & $\begin{array}{c}\text { For other } \\
\text { purposes }\end{array}$ & $\begin{array}{c}\text { Don't } \\
\text { know this } \\
\text { technology }\end{array}$ & $\begin{array}{c}\text { Not } \\
\text { Skilled } \\
\text { at All }\end{array}$ & $\begin{array}{c}\text { Not } \\
\text { Very } \\
\text { Skilled }\end{array}$ & Neutral & Skilled & $\begin{array}{c}\text { Very } \\
\text { Skilled }\end{array}$ \\
\hline $\begin{array}{l}\text { Use a computer to manage or manipulate } \\
\text { digital photos (e.g. using Photo, Dig. Image) }\end{array}$ & $\square$ & $\square$ & $\square$ & $\mathbf{1}$ & $\mathbf{2}$ & $\mathbf{3}$ & $\mathbf{4}$ & $\mathbf{5}$ \\
\hline $\begin{array}{l}\text { Use a computer to create presentations (e.g. } \\
\text { PowerPoint) }\end{array}$ & $\square$ & $\square$ & $\square$ & $\mathbf{1}$ & $\mathbf{2}$ & $\mathbf{3}$ & $\mathbf{4}$ & $\mathbf{5}$ \\
\hline $\begin{array}{l}\text { Use a computer to create or edit audio \& video } \\
\text { (e.g. iMovie, Movie Maker) }\end{array}$ & $\square$ & $\square$ & $\square$ & $\mathbf{1}$ & $\mathbf{2}$ & $\mathbf{3}$ & $\mathbf{4}$ & $\mathbf{5}$ \\
\hline Use a computer to play games & $\square$ & $\square$ & $\square$ & $\mathbf{1}$ & $\mathbf{2}$ & $\mathbf{3}$ & $\mathbf{4}$ & $\mathbf{5}$ \\
\hline $\begin{array}{l}\text { Use the Internet/web or a LAN to play } \\
\text { Network games }\end{array}$ & $\square$ & $\square$ & $\square$ & $\mathbf{1}$ & $\mathbf{2}$ & $\mathbf{3}$ & $\mathbf{4}$ & $\mathbf{5}$ \\
\hline $\begin{array}{l}\text { Use a hand-held computer (e.g. a PDA) as a } \\
\text { Personal organiser (e.g. diary, address book) }\end{array}$ & $\square$ & $\square$ & $\square$ & $\mathbf{1}$ & $\mathbf{2}$ & $\mathbf{3}$ & $\mathbf{4}$ & $\mathbf{5}$ \\
\hline $\begin{array}{l}\text { Use the web to access a portal, 'Course or } \\
\text { Learning Management System' }\end{array}$ & $\square$ & $\square$ & $\square$ & $\mathbf{1}$ & $\mathbf{2}$ & $\mathbf{3}$ & $\mathbf{4}$ & $\mathbf{5}$ \\
\hline
\end{tabular}




\begin{tabular}{|c|c|c|c|c|c|c|c|c|}
\hline Types of Technology & $\begin{array}{c}\text { For } \\
\text { learning }\end{array}$ & \begin{tabular}{|c|}
$\begin{array}{c}\text { For } \\
\text { other } \\
\text { purposes }\end{array}$ \\
\end{tabular} & $\begin{array}{l}\text { Don't } \\
\text { know this } \\
\text { technology }\end{array}$ & $\begin{array}{c}\text { Not } \\
\text { Skilled } \\
\text { at All }\end{array}$ & $\begin{array}{c}\text { Not } \\
\text { Very } \\
\text { Skilled }\end{array}$ & Neutral & Skilled & $\begin{array}{l}\text { Very } \\
\text { Skilled }\end{array}$ \\
\hline $\begin{array}{l}\text { Use the web to look up reference information } \\
\text { (e.g. online dictionaries) }\end{array}$ & $\square$ & a & $\square$ & 1 & 2 & 3 & 4 & 5 \\
\hline $\begin{array}{l}\text { Use the web for pastimes (e.g. for leisure } \\
\text { activities) }\end{array}$ & $\square$ & $\square$ & $\square$ & 1 & 2 & 3 & 4 & 5 \\
\hline $\begin{array}{l}\text { Use the web/Intemet to send or receive email } \\
\text { (e.g. Hotmail, Yahoo, Outlook) }\end{array}$ & $\square$ & $\square$ & $\square$ & 1 & 2 & 3 & 4 & 5 \\
\hline $\begin{array}{l}\text { Use the web/Internet for instant messaging / } \\
\text { Chat (e.g. MSN, Yahoo) }\end{array}$ & $\square$ & ם & $\square$ & 1 & 2 & 3 & 4 & 5 \\
\hline Use the web to build \& maintain a website & $\square$ & ם & $\square$ & 1 & 2 & 3 & 4 & 5 \\
\hline $\begin{array}{l}\text { Use social networking software on the web } \\
\text { (e.g. Face book) }\end{array}$ & $\square$ & 口 & $\square$ & 1 & 2 & 3 & 4 & 5 \\
\hline $\begin{array}{l}\text { Use the web to download podcasts (e.g. using } \\
\text { Juice, iT unes) }\end{array}$ & $\square$ & ם & $\square$ & 1 & 2 & 3 & 4 & 5 \\
\hline $\begin{array}{l}\text { Use the web to publish podcasts (e.g. using } \\
\text { Podifier, Podcaster, PodProducer) }\end{array}$ & $\square$ & 口 & $\square$ & 1 & 2 & 3 & 4 & 5 \\
\hline $\begin{array}{l}\text { Use the web to share photographs or other } \\
\text { Digital material (e.g. using blinklist, Flickr) }\end{array}$ & $\square$ & ם & $\square$ & 1 & 2 & 3 & 4 & 5 \\
\hline $\begin{array}{l}\text { Use the web to make phone calls (e.g. VoIP } \\
\text { using Skype) }\end{array}$ & $\square$ & $\square$ & $\square$ & 1 & 2 & 3 & 4 & 5 \\
\hline $\begin{array}{l}\text { Use the web for web conferencing (e.g. using a } \\
\text { webcam with Skype) }\end{array}$ & $\square$ & $\square$ & $\square$ & 1 & 2 & 3 & 4 & 5 \\
\hline Use the web to keep your own blog or vlog & $\square$ & ם & $\square$ & 1 & 2 & 3 & 4 & 5 \\
\hline $\begin{array}{l}\text { Use the web to read other peoples' blogs or } \\
\text { Volgs }\end{array}$ & $\square$ & 口 & $\square$ & 1 & 2 & 3 & 4 & 5 \\
\hline Use the web to comment on blogs or vlogs & $\square$ & ם & ם & 1 & 2 & 3 & 4 & 5 \\
\hline $\begin{array}{l}\text { Use the web to contribute to the development } \\
\text { of a Wiki }\end{array}$ & $\square$ & 口 & $\square$ & 1 & 2 & 3 & 4 & 5 \\
\hline Use a mobile phone to text / MSM people & $\square$ & ם & $\square$ & 1 & 2 & 3 & 4 & 5 \\
\hline $\begin{array}{l}\text { Use a mobile phone to access information/ } \\
\text { services on the web }\end{array}$ & $\square$ & $\square$ & $\square$ & 1 & 2 & 3 & 4 & 5 \\
\hline Use a mobile phone to send or receive email & $\square$ & ם & $\square$ & 1 & 2 & 3 & 4 & 5 \\
\hline
\end{tabular}

\section{Section 4: Perceived Usefulness of Technology in Learning}

Below is a list of different ways in which technology may be used to help you with your studies at University. Please indicate your agreement with how useful each of the following technologies is in your study; circle the number that best represents your opinion - 1 indicates "Strongly disagree" and 5 indicates "Strongly agree". If you are not sure about a particular technology, please tick "Don't know".

\begin{tabular}{|l|c|c|c|c|c|c|}
\hline $\begin{array}{l}\text { In your studies, how useful do you think it would } \\
\text { be to: }\end{array}$ & $\begin{array}{c}\text { Strongly } \\
\text { disagree }\end{array}$ & Disagree & Neutral & Agree & $\begin{array}{c}\text { Strongly } \\
\text { agree }\end{array}$ & $\begin{array}{c}\text { Don't } \\
\text { Know }\end{array}$ \\
\hline Design and build web pages? & $\mathbf{1}$ & $\mathbf{2}$ & $\mathbf{3}$ & $\mathbf{4}$ & $\mathbf{5}$ & $\mathbf{\square}$ \\
\hline Create and present multimedia shows (e.g. Power Point)? & $\mathbf{1}$ & $\mathbf{2}$ & $\mathbf{3}$ & $\mathbf{4}$ & $\mathbf{5}$ & $\mathbf{\square}$ \\
\hline $\begin{array}{l}\text { Create and present audio/ video (e.g. i Movie, Movie } \\
\text { Maker)? }\end{array}$ & $\mathbf{1}$ & $\mathbf{2}$ & $\mathbf{3}$ & $\mathbf{4}$ & $\mathbf{5}$ & $\square$ \\
\hline Create spreadsheets (Excel, etc.)? & $\mathbf{1}$ & $\mathbf{2}$ & $\mathbf{3}$ & $\mathbf{4}$ & $\mathbf{5}$ & 口 \\
\hline Use programming languages (C++, Java, etc.)? & $\mathbf{1}$ & $\mathbf{2}$ & $\mathbf{3}$ & $\mathbf{4}$ & $\mathbf{5}$ & 口 \\
\hline $\begin{array}{l}\text { Use Matlab to simplify the implementation of numerical } \\
\text { linear algebra routines? }\end{array}$ & $\mathbf{1}$ & $\mathbf{2}$ & $\mathbf{3}$ & $\mathbf{4}$ & $\mathbf{5}$ & $\square$ \\
\hline Use Labview to develop high-performance applications? & $\mathbf{1}$ & $\mathbf{2}$ & $\mathbf{3}$ & $\mathbf{4}$ & $\mathbf{5}$ & $\square$ \\
\hline
\end{tabular}




\begin{tabular}{|c|c|c|c|c|c|c|}
\hline $\begin{array}{l}\text { In your studies, how useful do you think it would } \\
\text { be to: }\end{array}$ & $\begin{array}{l}\text { Strongly } \\
\text { disagree }\end{array}$ & Disagree & Neutral & Agree & $\begin{array}{l}\text { Strongly } \\
\text { agree }\end{array}$ & $\begin{array}{l}\text { Don't } \\
\text { Know }\end{array}$ \\
\hline $\begin{array}{l}\text { Download or access online audio/video recordings of } \\
\text { lectures? }\end{array}$ & 1 & 2 & 3 & 4 & 5 & ם \\
\hline $\begin{array}{l}\text { Download or access online audio/video recordings of } \\
\text { supplementary content material? }\end{array}$ & 1 & 2 & 3 & 4 & 5 & ם \\
\hline $\begin{array}{l}\text { Use the web to access University based services (e.g. } \\
\text { enrolment, sign up for tutes, pay fees)? }\end{array}$ & 1 & 2 & 3 & 4 & 5 & ם \\
\hline $\begin{array}{l}\text { Use your mobile phone to access web-based University } \\
\text { services information or services (e.g. enrolment, sign up for } \\
\text { tutes, pay fees)? }\end{array}$ & 1 & 2 & 3 & 4 & 5 & ב \\
\hline $\begin{array}{l}\text { Use instant messaging/chat (e.g. MSN, Yahoo, ICQ) on the } \\
\text { web to communicate/ collaborate with other students in the } \\
\text { course? }\end{array}$ & 1 & 2 & 3 & 4 & 5 & 口 \\
\hline $\begin{array}{l}\text { Use instant messaging/chat (e.g. MSN, Yahoo) on the web } \\
\text { to communicate with lecturing and administrative staff? }\end{array}$ & 1 & 2 & 3 & 4 & 5 & ב \\
\hline $\begin{array}{l}\text { Use social networking software (e.g. Facebook) on the web } \\
\text { to communicate/collaborate with other students? }\end{array}$ & 1 & 2 & 3 & 4 & 5 & ם \\
\hline $\begin{array}{l}\text { Use the web to share digital files related to your course (e.g. } \\
\text { sharing photos, audio files, movies, websites, etc.)? }\end{array}$ & 1 & 2 & 3 & 4 & 5 & ם \\
\hline $\begin{array}{l}\text { Use web conferencing or video } \\
\text { communicate/collaborate with other students? }\end{array}$ & 1 & 2 & 3 & 4 & 5 & ם \\
\hline Keep your own blogs as part of your course requirements? & 1 & 2 & 3 & 4 & 5 & $\square$ \\
\hline $\begin{array}{l}\text { Contribute to another blog as part of your course } \\
\text { requirements? }\end{array}$ & 1 & 2 & 3 & 4 & 5 & $\square$ \\
\hline $\begin{array}{l}\text { Contribute with other students to the development of wiki } \\
\text { as part of your course requirements? }\end{array}$ & 1 & 2 & 3 & 4 & 5 & $\square$ \\
\hline $\begin{array}{l}\text { Receive grades/marks from your Lecturer via text message } \\
\text { on your mobile phone? }\end{array}$ & 1 & 2 & 3 & 4 & 5 & $\square$ \\
\hline $\begin{array}{l}\text { Receive pre-class discussion questions from your Lecturer } \\
\text { via text message on your mobile phone? }\end{array}$ & 1 & 2 & 3 & 4 & 5 & $\square$ \\
\hline $\begin{array}{l}\text { Receive administrative information about the course via } \\
\text { text message on your mobile phone (e.g. timetable or } \\
\text { assessment changes, information on new learning } \\
\text { resources? }\end{array}$ & 1 & 2 & 3 & 4 & 5 & $\square$ \\
\hline
\end{tabular}

Please list three ways in which you think the technologies that you use in your everyday life could be useful in your studies.

1)

2)

3)

\section{Section 5: Challenges of ICT and e-Learning Practice}

What challenges do you face as a student when using ICT and e-learning? (E.g. a role change, learning methods, doing assignments, etc.) 


\section{Section 6: Technological Characteristics and Technical Support}

Please rate the following statements. For each item. circle the number that best represents your opinion -1 indicates "Very poor" and 5 indicates "Very good".

\begin{tabular}{|c|c|c|c|c|c|}
\hline Statement & Very poor & Poor & Average & Good & Very Good \\
\hline The quality of the Intemet access in the institute & 1 & 2 & 3 & 4 & 5 \\
\hline The necessary ICT infrastructure & 1 & 2 & 3 & 4 & 5 \\
\hline The quality of the technology used in classes & 1 & 2 & 3 & 4 & 5 \\
\hline The ease of use of technology & 1 & 2 & 3 & 4 & 5 \\
\hline $\begin{array}{l}\text { The extent to which the courses relied on the use of } \\
\text { technology in the classrooms }\end{array}$ & 1 & 2 & 3 & 4 & 5 \\
\hline $\begin{array}{l}\text { The extent to which the courses relied on the use of } \\
\text { technology at home }\end{array}$ & 1 & 2 & 3 & 4 & 5 \\
\hline $\begin{array}{l}\text { The degree of confidence you had that classes } \\
\text { would not be interrupted or cancelled due to } \\
\text { technical problems }\end{array}$ & 1 & 2 & 3 & 4 & 5 \\
\hline The quality of technical support provided & 1 & 2 & 3 & 4 & 5 \\
\hline $\begin{array}{l}\text { The overall usefulness of technology used in } \\
\text { classes }\end{array}$ & 1 & 2 & 3 & 4 & 5 \\
\hline
\end{tabular}

\section{Section 7: Attitude towards ICT and e-Learning}

Please indicate your agreement with the following statements; circle the number that best represents your opinion - 1 indicates "Strongly disagree" and 5 indicates "Strongly agree".

\begin{tabular}{|c|c|c|c|c|c|}
\hline Statement & $\begin{array}{l}\text { Strongly } \\
\text { disagree }\end{array}$ & Disagree & Neutral & Agree & $\begin{array}{c}\text { Strongly } \\
\text { agree }\end{array}$ \\
\hline I feel confident in using computers. & 1 & 2 & 3 & 4 & 5 \\
\hline I enjoy using ICT for my studies & 1 & 2 & 3 & 4 & 5 \\
\hline $\begin{array}{l}\text { I believe that e-learning gives me the opportunity } \\
\text { to acquire new knowledge }\end{array}$ & 1 & 2 & 3 & 4 & 5 \\
\hline $\begin{array}{l}\text { I believe that e-learning enhances my learning } \\
\text { experience }\end{array}$ & 1 & 2 & 3 & 4 & 5 \\
\hline $\begin{array}{l}\text { I believe that convenience is an important feature } \\
\text { of e-learning }\end{array}$ & 1 & 2 & 3 & 4 & 5 \\
\hline $\begin{array}{l}\text { E-learning increases the quality of learning because } \\
\text { it integrates all forms of media (print, audio, video) }\end{array}$ & 1 & 2 & 3 & 4 & 5 \\
\hline $\begin{array}{l}\text { Adopting ICT and e-learning allows for increased } \\
\text { student satisfaction }\end{array}$ & 1 & 2 & 3 & 4 & 5 \\
\hline $\begin{array}{l}\text { I would be interested in studying courses that use } \\
\text { e-learning }\end{array}$ & 1 & 2 & 3 & 4 & 5 \\
\hline
\end{tabular}

\section{Section 8: Other Comments}

Any additional comments or suggestions.




\section{Appendix B \\ Model of student attitudes towards ICT and e-learning}

\begin{tabular}{|l|c|c|c|c|}
\hline \multicolumn{6}{|c|}{ Model Summary } \\
\hline Model & $\mathrm{R}$ & R Square & Adjusted R Square & $\begin{array}{c}\text { Std. Error of the Esti- } \\
\text { mate }\end{array}$ \\
\hline 1 & $.546^{\mathrm{a}}$ & .298 & .246 & .511 \\
\hline
\end{tabular}

ANOVA $^{\text {a }}$

\begin{tabular}{|l|l|r|r|r|r|r|}
\hline \multicolumn{2}{|l|}{ Model } & Sum of Squares & df & Mean Square & F & \multicolumn{1}{c|}{ Sig. } \\
\hline \multirow{4}{*}{1} & Regression & 5.987 & 4 & 1.497 & 5.730 & $.001^{\mathrm{b}}$ \\
\cline { 2 - 8 } & Residual & 14.105 & 54 & .261 & & \\
\cline { 2 - 8 } & Total & 20.093 & 58 & & & \\
\hline \multirow{2}{*}{} & & & & & & \\
\hline
\end{tabular}

a. Dependent Variable: Attitude towards ICT and e-learning

b. Predictors: (Constant), Use for learning, Level of skill, satisfaction, Access

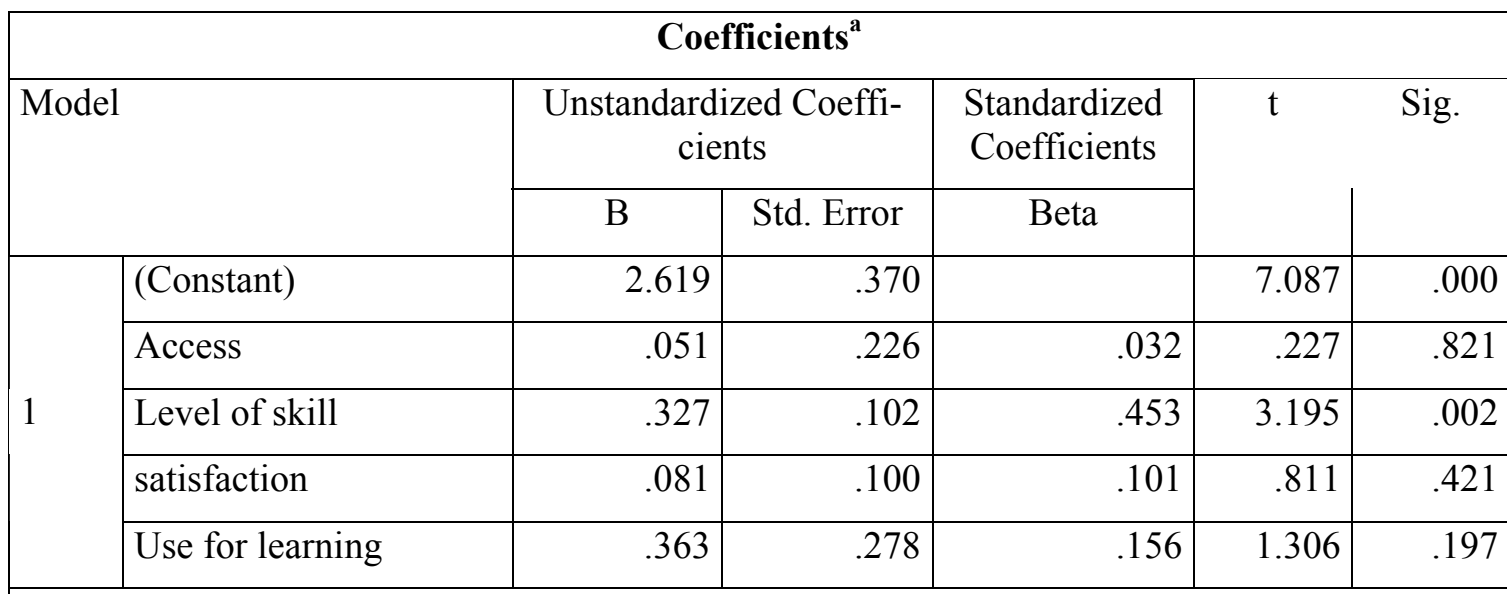

a. Dependent Variable: Attitude towards ICT and e-learning 


\section{Biographies}

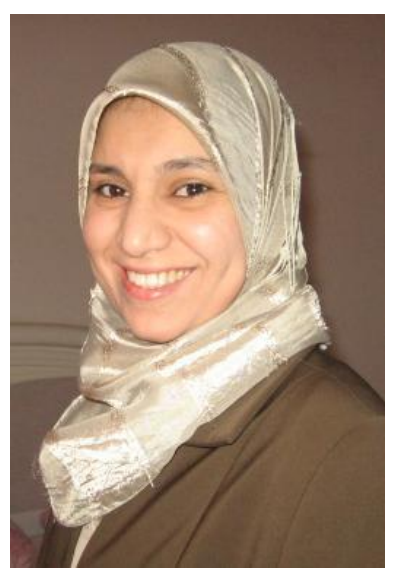

Mrs Amal Rhema is a PhD candidate in the School of Engineering and Science at Victoria University in Melbourne, Australia where she is currently undertaking a research project entitled "An analysis of experiences and perceptions of technology-based learning in higher education institutions in Libya: informing the advancement of e-learning through case studies".

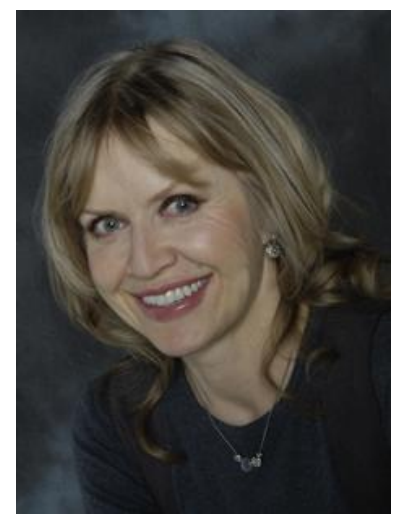

Dr Iwona Miliszewska is Associate Professor in computer science at Victoria University in Melbourne, Australia. She has led and participated in research projects involving transnational education, effective teaching methods, females in ICT, and technology supported learning and has published in these areas. 